\title{
GAMBARAN PENGGUNAAN BAHAN ANESTESI LOKAL UNTUK PENCABUTAN GIGI TETAP OLEH DOKTER GIGI DI KOTA MANADO
}

\author{
${ }^{1}$ Muhammad Ikhsan \\ ${ }^{2}$ Ni Wayan Mariati \\ ${ }^{2}$ Christy Mintjelungan
}

\author{
${ }^{1}$ Kandidat Skripsi Program Studi Kedokteran Gigi Fakultas Kedokteran \\ Universitas Sam Ratulangi Manado \\ ${ }^{2}$ Program Studi Kedokteran Gigi Fakultas Kedokteran \\ Universitas Sam Ratulangi Manado \\ Email: muhammad_ikhsan@live.com
}

\begin{abstract}
Local anesthetic agent is one of the materials most commonly used in dentistry. Local anesthetic agent used for relieving pain arising from dental procedures. Local anesthetic agent is divided into two groups, namely esters and amides. This study provides information on the availability of local anesthetic agent in Manado. The purpose of this study to describe the use of local anesthesia by a dentist in the city of Manado. This type of research is a descriptive study and sampling was performed with a total sampling method. Retrieval of data by means of questionnaires by a dentist who practiced in the city of Manado. The number of samples in this study were 31 dentists. The results found that 22 dentists (70.96\%) using the amide groups lidocaine $\mathrm{HCl} 2 \%$ and 2 dentists (6,45\%) procaine and benzocaine is an ester group. The effectiveness of the local anesthetic agent is a major reason in the selection of a local anesthetic agent that is $90.32 \%$ or 28 dentists.
\end{abstract}

Keywords: local anesthetic agents.

\begin{abstract}
Abstrak: Bahan anestesi lokal merupakan salah satu bahan yang paling sering digunakan dalam kedokteran gigi. Bahan anestesi lokal digunakan untuk menghilangkan rasa sakit yang timbul akibat prosedur kedokteran gigi. Bahan anestesi lokal terbagi dua golongan yaitu ester dan amida. Penelitian ini memberikan informasi ketersediaan bahan anestesi lokal di Manado. Tujuan penelitian ini untuk mengetahui gambaran penggunaan bahan anestesi lokal oleh dokter gigi di kota Manado. Jenis penelitian yang digunakan yaitu penelitian deskriptif dan pengambilan sampel dilakukan dengan metode total sampling. Pengambilan data dengan cara pengisian kuesioner oleh dokter gigi yang berpraktik di kota Manado. Jumlah sampel dalam penelitian ini sebanyak 31 dokter gigi. Hasil penelitian mendapati bahwa 22 dokter gigi (70,96\%) menggunakan golongan amida yaitu lidokain $\mathrm{HCl}$ 2\% dan 2 dokter gigi (6,45\%) golongan ester yaitu prokain dan benzokain. Keefektifan bahan anestesi lokal merupakan alasan utama dalam pemilihan bahan anestesi lokal yaitu 90,32\% atau 28 orang dokter gigi.
\end{abstract}

Kata kunci: bahan anestesi lokal.

Bahan anestesi lokal merupakan salah satu bahan yang paling sering digunakan dalam kedokteran gigi, bahkan menjadi bahan yang mutlak digunakan dalam praktek dokter gigi sehari-hari. ${ }^{1,2}$ Bahan anestesi lokal digunakan untuk menghilangkan rasa sakit yang timbul akibat prosedur kedokteran gigi yang dilakukan. ${ }^{2}$ Bahan anestesi lokal terbagi atas dua golongan yaitu ester dan amida. ${ }^{3,4}$ Jenis bahan anestesi yang termasuk dalam golongan ester diantaranya yaitu kokain, prokain, 2-kloroprokain, tetrakain dan benzokain sedangkan yang termasuk dalam golongan amida diantaranya yaitu lidokain, mepivakain, bupivakain, prilokain, etidokain dan artikain. ${ }^{4-7}$ 
106 Jurnal e-GiGi (eG), Volume 1, Nomor 2, September 2013, hlm. 105-114

Beberapa penelitian dilakukan untuk mengetahui jenis bahan anestesi lokal yang digunakan oleh dokter gigi dalam praktek sehari-hari. Sebuah survei mengenai jenis bahan anestesi lokal yang digunakan oleh dokter gigi dilakukan oleh Gaffen dan Haas selama tahun 2007. Keduanya menemukan bahwa lidokain dengan epinefrin 1:100.000 merupakan bahan anestesi lokal yang paling banyak digunakan oleh dokter gigi di Ontario yaitu 37,31\%. Artikain dengan epinefrin 1:200.000 menduduki peringkat kedua dengan persentase penggunaan mencapai 27,04\%. ${ }^{1}$ Survei lain yang dilakukan oleh Kirova dkk, pada bulan juni dan oktober 2003 dan pada bulan maret dan april 2004, menemukan bahwa dokter gigi di Bulgaria paling sering menggunakan Ubistesine yaitu sebanyak 52,27\% diikuti pengunaan artikain sebanyak 43,18\%. Lidokain hanya menempati peringkat ke-4 dengan persentase penggunaan $20,90 \%$. $^{2}$ Adapun penelitian yang dilakukan oleh Corbett dkk pada dokter gigi di United Kingdom (UK) mengenai bahan anestesi lokal yang digunakan oleh dokter gigi yang telah berpengalaman dan dokter li $n$ baru ( $\leq 5$ tahun) antara tahun 2002 dan tahun 2003, menemukan bahwa lidokain dengan epinefrin merupakan bahan anestesi lokal yang paling banyak digunakan dengan persentase penggunaan yaitu 94\%. Prilokain dengan felipressin merupakan bahan anestesi lokal yang paling sering digunakan setelah lidokain dengan persentase penggunaan yaitu $74 \%$. Artikain yang banyak digunakan di Ontario dan Bulgaria hanya menempati tempat ketiga diikuti dengan mepivakain. ${ }^{7}$

Melihat banyaknya jenis bahan anestesi lokal yang ada diikuti penggunaan yang beragam di berbagai negara, penulis tertarik untuk melakukan penelitian mengenai gambaran penggunaan bahan anestesi lokal pada pencabutan gigi oleh dokter gigi di kota Manado. Selain data penggunaan bahan anestesi lokal di Indonesia khususnya Manado masih sangat minim, penelitian ini juga dapat memberikan informasi mengenai pilihan bahan anestesi yang ada di Manado. Hal ini dapat memberikan informasi ketersediaan bahan anestesi lokal yang ada di Manado sehingga dokter gigi dapat mengetahui pilihan bahan anestesi yang tersedia.

Tujuan dari penelitian ini ialah untuk mengetahui gambaran penggunaan bahan anestesi lokal untuk pencabutan gigi tetap oleh dokter gigi di kota Manado, dengan tujuan khusus Untuk mengetahui gambaran penggunaan bahan anestesi berdasarkan golongan ester, amida dan kombinasi keduanya serta alasan penggunaanya.

\section{BAHAN DAN METODE}

Penelitian ini merupakan penelitian deskriptif. Besar sampel yang diteliti berjumlah 31 dokter gigi diambil dengan teknik total sampling.

Penelitian dilakukan dengan terlebih dahulu meminta izin untuk melakukan penelitian pada setiap dokter gigi yang dikunjungi. Pengambilan data dilakukan dengan menggunakan kuesioner yang diisi oleh dokter gigi dengan izin surat penelitian yang disertakan kuesioner. Pemberian surat penelitian dan kuesioner kepada dokter gigi yang berpraktek di kota Manado.

Data yang di dapat kemudian diolah berdasarkan distribusi frekuensi dan disajikan dalam bentuk tabel lalu dianalisis berdasarkan hasil persentase.

\section{HASIL}

\section{Karakteristik Subjek}

Subjek yang diteliti pada penelitian ini ialah dokter-dokter gigi yang melakukan tindakan pencabutan gigi dan berpraktik di kota Manado. Populasi terjangkau dari penelitian ini berjumlah 31 orang dokter gigi, dari jumlah subjek penelitian sebanyak 43 orang dokter gigi, berdasarkan data yang didapatkan dari dinas kesehatan Manado dapat dilihat pada Tabel 2.

Dari Tabel 2 terlihat bahwa subjek penelitian berdasarkan lama berpraktik sebagai dokter gigi dengan lama berpraktik lebih dari 20 tahun berjumlah 7 orang dokter gigi (22,58\%), 16 sampai 20 tahun 7 orang dokter gigi (22,58\%), 11 sampai 15 
Ikhsan, Mariati, Mintjelungan; Gambaran Penggunaan Bahan Anestesi Lokal... 107

tahun 7 orang dokter gigi (22,58\%), 6 sampai 10 tahun 5 orang dokter gigi $(16,12 \%)$ dan kurang dari 5 tahun 5 orang dokter gigi (16,12\%).

Tabel 2. Distribusi subjek penelitian berdasarkan lama praktik sebagai dokter gigi.

\begin{tabular}{|c|c|c|c|}
\hline \multirow{2}{*}{$\begin{array}{c}\text { Subjek penelitian } \\
\text { berdasarkan lama } \\
\text { praktik sebagai } \\
\text { dokter gigi }\end{array}$} & \multicolumn{2}{|c|}{ Jumlah (n) } & \multirow[b]{2}{*}{$\%$} \\
\hline & $\begin{array}{c}\text { Laki- } \\
\text { laki }\end{array}$ & Perempuan & \\
\hline$>20$ tahun & 5 & 2 & 22,58 \\
\hline 16 - 20 tahun & 6 & 1 & 22,58 \\
\hline 11 - 15 tahun & 1 & 6 & 22,58 \\
\hline 6 - 10 tahun & 1 & 4 & 16,12 \\
\hline$<5$ tahun & 1 & 4 & 16,12 \\
\hline \multirow[b]{2}{*}{ Total } & 14 & 17 & \multirow[b]{2}{*}{100} \\
\hline & & 31 & \\
\hline
\end{tabular}

Penggunaan bahan anestesi lokal untuk pencabutan gigi tetap oleh dokter gigi di Kota Manado

Penggunaan bahan anestesi lokal diukur dengan menggunakan kuesioner yang terdiri dari 12 pertanyaan. Hasil penelitian dijabarkan berdasarkan setiap nomor pertanyaan berikut ini:

Kriteria bahan anestesi lokal yang dilihat dokter gigi dalam memilih bahan anestesi lokal

Kriteria bahan anestesi lokal yang dilihat dokter gigi dalam memilih bahan anestesi lokal dapat dilihat pada Tabel 3.

Tabel 3. Distribusi frekuensi berdasarkan kriteria yang dilihat dokter gigi dalam memilih bahan anestesi lokal

\begin{tabular}{lcc}
\hline $\begin{array}{l}\text { Kriteria yang dokter gigi lihat } \\
\text { dari bahan anestesi }\end{array}$ & n & \% \\
\hline Keefektifan bahan anestesi lokal & 28 & 56 \\
Harga bahan anestesi lokal & 6 & 12 \\
Ketersediaan bahan anestesi lokal & 9 & 18 \\
Golongan bahan anestesi lokal & 7 & 14 \\
\hline Total & 50 & 100 \\
\hline
\end{tabular}

Tabel 3 menunjukkan dokter gigi yang menjawab pilihan jawaban berdasarkan keefektifan bahan anestesi lokal berjumlah
28 orang (56\%), sedangkan yang menjawab berdasarkan harga bahan anestesi berjumlah 6 orang (12\%), berdasarkan ketersediaan bahan anestesi lokal berjumlah 9 orang (9\%) dan berdasarkan golongan bahan anestesi lokal berjumlah 7 orang (14\%).

\section{Bahan anestesi lokal yang digunakan untuk pencabutan gigi tetap}

Bahan anestesi lokal yang digunakan oleh dokter gigi untuk pencabutan gigi tetap dapat dilihat pada Tabel 4.

Tabel 4. Distribusi frekuensi berdasarkan bahan anestesi yang digunakan untuk pencabutan gigi.

\begin{tabular}{|c|c|c|}
\hline Bahan anestesi lokal & $\mathbf{N}$ & $\%$ \\
\hline Lidokain $\mathrm{HCl} 2 \%$ & 13 & 41,93 \\
\hline $\begin{array}{lll} & \text { Lidokain } & \mathrm{HCl} \\
\text { 1:100.000 } & \end{array}$ & 6 & 19,35 \\
\hline - Lidokain HCl 2\% 1:80.000 & 4 & 12,90 \\
\hline Artikain $\mathrm{HCl} 4$ \% & 2 & 6,45 \\
\hline $\begin{array}{llll}\text { - Artikain } & \mathrm{HCl} & 4 & \% \\
1: 100.000 & & & \end{array}$ & 3 & 9,67 \\
\hline Mepivakain $\mathrm{HCl}$ 2\% & 1 & 3,22 \\
\hline Prokain $\mathrm{HCl}$ & 1 & 3,22 \\
\hline Lainnya & 1 & 3,22 \\
\hline Total & 31 & 100 \\
\hline
\end{tabular}

Berdasarkan Tabel 4 terlihat persentase tertinggi yaitu $41,93 \%$ atau 13 orang dokter gigi menggunakan lidokain $\mathrm{HCl} 2 \%, 6$ orang atau 19,35\% menggunakan lidokain $1: 100.000,4$ orang atau 12,90\% menggunakan lidokain 1:80.000, 2 orang atau 6,45\% menggunakan artikain $\mathrm{HCl} 4 \%$, 3 orang atau 9,67\% menggunakan artikain $\mathrm{HCl}$ 4\% 1:100.000 dan masing-masing 1 orang atau 3,22\% dokter gigi menggunakan mepivakain $\mathrm{HCl} 2 \%$, prokain $\mathrm{HCl}$ dan jenis lain yaitu ziakain.

\section{Alasan dokter gigi dalam memilih bahan anestesi lokal}

Alasan dokter gigi dalam memilih bahan anestesi lokal dapat dilihat pada Tabel 5.

Berdasarkan Tabel 5 terlihat persentase tertinggi yaitu $74,19 \%$ atau 22 orang menjawab penggunaan bahan anestesi harus memenuhi syarat ideal bahan, mulai kerja cepat dan bekerja lama serta tidak menyebabkan alergi. Persentase terendah 
108 Jurnal e-GiGi (eG), Volume 1, Nomor 2, September 2013, hlm. 105-114

yaitu 3,22\% atau 1 orang saja yang menjawab hanya mengetahui bahan anestesi tersebut.

Tabel 5. Distribusi frekuensi berdasarkan alasan dokter gigi menggunakan bahan anestesi lokal

\begin{tabular}{lccc}
\hline $\begin{array}{l}\text { Alasan dokter gigi memilih bahan } \\
\text { anestesi lokal }\end{array}$ & N & \% \\
\hline $\begin{array}{l}\text { Memenuhi syarat ideal bahan } \\
\text { anestesi lokal, mula kerja cepat, }\end{array}$ & & 74,19 \\
$\begin{array}{l}\text { waktu kerja yang lama dan tidak } \\
\text { meyebabkan alergi }\end{array}$ & & \\
$\begin{array}{l}\text { Bahan tersebut murah, sudah } \\
\text { terkenal dan paling banyak dijual }\end{array}$ & 5 & 16,12 \\
$\begin{array}{l}\text { Mengikuti bahan yang digunakan } \\
\text { dokter lain }\end{array}$ & 2 & 6,45 \\
Hanya tahu bahan anestesi tersebut & 1 & 3,22 \\
\hline Total & 31 & 100 \\
\hline
\end{tabular}

\section{Penggunaan bahan kombinasi anestesi lokal}

Penggunaan bahan kombinasi anestesi lokal oleh dokter gigi di Kota Manado dapat dilihat pada Tabel 6.

Tabel 6. Distribusi frekuensi berdasarkan penggunaan bahan kombinasi anestesi lokal.

\begin{tabular}{lcc}
\hline $\begin{array}{l}\text { Penggunaan bahan } \\
\text { kombinasi anestesi lokal }\end{array}$ & n & \% \\
\hline Ya & 17 & 54,83 \\
Tidak & 14 & 45,16 \\
\hline Total & 31 & 100 \\
\hline
\end{tabular}

Tabel 6 menunjukkan dari 31 dokter gigi yang memberikan jawaban dari pertanyaan tentang penggunaan bahan kombinasi anestesi lokal, 17 orang atau $54,83 \%$ menjawab ya dan 14 orang atau 45,16\% memberikan jawaban tidak.

\section{Alasan dokter gigi menggunakan kombinasi bahan anestesi lokal}

Alasan dokter gigi dalam menggunakan kombinasi bahan anestesi lokal dapat dilihat pada Tabel 7.

Berdasarkan Tabel 7 terlihat persentase tertinggi yaitu $35,48 \%$ atau 11 orang memberikan jawaban bahwa penggunaan kombinasi bahan anestesi lokal dilakukan ketika pasien takut terhadap rasa sakit sehingga butuh anestesi topikal. Sedangkan 1 orang atau 3,22\% merupakan persentase terendah yang menjawab digunakan ketika pasien masih merasa sakit.

Tabel 7. Distribusi frekuensi berdasarkan penggunaan kombinasi bahan anestesi lokal pada keadaan tertentu.

\begin{tabular}{lcc}
\hline $\begin{array}{l}\text { Alasan dokter gigi dalam } \\
\text { menggunakan kombinasi bahan } \\
\text { anestesi lokal }\end{array}$ & n & \% \\
\hline $\begin{array}{l}\text { Pasien takut terhadap rasa sakit } \\
\text { sehingga butuh anestesi topikal } \\
\text { terlebih dahulu }\end{array}$ & 11 & 35,48 \\
$\begin{array}{l}\text { Sudah menjadi prosedur di tempat } \\
\text { praktek dokter untuk }\end{array}$ & 7 & 22,58 \\
$\begin{array}{l}\text { menghilangkan ketidaknyamanan } \\
\text { pasien }\end{array}$ & & \\
$\begin{array}{l}\text { Pasien anak } \\
\text { Pasien meminta agar diberi anestesi } \\
\text { topikal terlebih dahulu }\end{array}$ & 9 & 29,03 \\
Lainnya & & 9,677 \\
\hline Total & 1 & 31,22 \\
\hline
\end{tabular}

\section{Jenis bahan kombinasi anestesi lokal yang dokter gigi gunakan}

Jenis bahan kombinasi anestesi lokal yang digunakan oleh dokter gigi dapat dilihat pada Tabel 8 .

Tabel 8. Distribusi frekuensi berdasarkan jenis bahan anestesi yang dokter gigi gunakan untuk kombinasi

\begin{tabular}{lcc}
\hline $\begin{array}{l}\text { Jenis bahan kombinasi anestesi } \\
\text { lokal }\end{array}$ & n & \% \\
\hline Benzokain dan lidokain & 7 & 22,58 \\
Benzokain dan artikain & 1 & 3,22 \\
$\begin{array}{l}\text { Benzokain dan prokain } \\
\text { EMLA dan lidokain }\end{array}$ & 2 & 6,45 \\
$\begin{array}{l}\text { Lainnya } \\
\text { Tidak menggunakan kombinasi } \\
\text { anestesi }\end{array}$ & 1 & 3,22 \\
\hline Total & 14 & 19,35 \\
& & \\
\hline
\end{tabular}

Tabel 8 menunjukkan jumlah dokter gigi yang menggunakan jenis-jenis bahan kombinasi anestesi lokal, 7 orang atau $22,58 \%$ menggunakan benzokain dan lidokain, masing-masing 1 orang atau 3,22\% 
Ikhsan, Mariati, Mintjelungan; Gambaran Penggunaan Bahan Anestesi Lokal... 109

menggunakan benzokain dan artikain, serta EMLA dan lidokain dan 6,41\% atau 2 orang yang menggunakan benzokain dan prokain.

\section{Alasan dokter gigi tidak menggunakan bahan kombinasi anestesi lokal}

Alasan dokter gigi tidak pernah menggunakan bahan kombinasi anestesi lokal dapat dilihat pada Tabel 9.

Tabel 9. Distribusi frekuensi berdasarkan alasan dokter gigi tidak pernah menggunakan kombinasi bahan anestesi.

\begin{tabular}{llll}
\hline $\begin{array}{l}\text { Alasan dokter gigi tidak } \\
\text { menggunakan kombinasi } \\
\text { anestesi }\end{array}$ & $\begin{array}{r}\text { bahan } \\
\text { n }\end{array}$ & \% \\
\hline $\begin{array}{l}\text { Tidak perlu karena dengan satu jenis } \\
\text { bahan sudah cukup } \\
\text { Belum ada pasien yang meminta } \\
\text { untuk dilakukan anestesi topikal }\end{array}$ & 12 & 38,70 \\
$\begin{array}{l}\text { Anestesi topikal tidak terlalu } \\
\text { berpengaruh ketika akan dilakukan } \\
\text { injeksi }\end{array}$ & 1 & 3,22 \\
$\begin{array}{l}\text { Menggunakan bahan kombinasi } \\
\text { anestesi }\end{array}$ & 17 & 54,83 \\
\hline Total & 31 & 100 \\
\hline
\end{tabular}

Berdasarkan Tabel 9 terlihat berbagai alasan dokter tidak pernah menggunakan kombinasi bahan anestesi, 12 orang atau 38,70\% memberikan jawaban bahwa tidak perlu karena dengan satu jenis bahan sudah cukup. Sedangkan 3,22\% atau masingmasing 1 orang memberikan jawaban belum ada pasien yang meminta untuk dilakukan anestesi topikal, dan anestesi topikal tidak terlalu berpengaruh ketika akan dilakukan injeksi.

\section{Penggunaan jenis bahan anestesi lainnya}

Penggunaan jenis bahan anestesi lainnya yang pernah atau sedang digunakan dapat dilihat pada Tabel 10.

Tabel 10 menunjukkan dari 31 dokter gigi yang memberikan jawaban dari pertanyaan tentang pemakaian jenis bahan anestesi lain, 16 orang atau 51,61\% menjawab ya dan 15 orang atau 48,38\% memberikan jawaban tidak.
Tabel 10. Distribusi frekuensi berdasarkan pemakaian jenis bahan anestesi lainnya.

\begin{tabular}{lcc}
\hline $\begin{array}{l}\text { Penggunaan jenis } \\
\text { bahan anestesi lainnya }\end{array}$ & $\mathbf{n}$ & $\mathbf{\%}$ \\
\hline Ya & 16 & 51,61 \\
Tidak & 15 & 48,38 \\
\hline Total & 31 & 100 \\
\hline
\end{tabular}

\section{Jenis bahan anestesi yang dokter gigi gunakan selain bahan anestesi yang telah disebutkan}

Jenis bahan anestesi yang dokter gigi gunakan selain bahan anestesi yang telah disebutkan dapat dilihat pada Tabel 11.

Tabel 11. Distribusi frekuensi berdasarkan jenis bahan anestesi yang dokter gigi gunakan selain bahan anestesi yang disebutkan sebelumnya.

\begin{tabular}{llcc}
\hline $\begin{array}{l}\text { Bahan anestesi lokal yang } \\
\text { digunakan selain } \\
\text { sudah disebutkan }\end{array}$ & $\begin{array}{c}\text { yang } \\
\text { yadokain HCl 2\% }\end{array}$ & n & \% \\
\hline $\begin{array}{l}\text { Lidoka } \\
\text { Artikain HCl 4\% }\end{array}$ & 10 & 32,25 \\
Mepivakain HCl 2\% & 2 & 6,45 \\
Jenis lain & 2 & 6,45 \\
$\begin{array}{l}\text { Tidak menggunakan } \\
\text { anestesi lain }\end{array}$ & 2 & 6,45 \\
Total bahan & 15 & 48,38 \\
\hline & & \\
\hline
\end{tabular}

Berdasarkan tabel 11 diketahui 10 orang atau 32,25\% menggunakan lidokain $\mathrm{HCl} 2 \%$ diantaranya 1 orang menggunakan perbandingan epinefrin 1:100.000 dan 3 orang menggunakan perbandingan epinefrin 1:80.000, diikuti 1 orang atau 3,22\% menggunakan artikain $\mathrm{HCl} 4 \%$, dan masingmasing 2 orang atau 6,45\% menggunakan mepivakain $\mathrm{HCl} 2 \%$ dan anestesi lainnya yaitu benzokain dan chlor etil.

\section{Alasan dokter gigi tidak pernah meng- gunakan bahan anestesi lainnya}

Alasan dokter gigi tidak pernah menggunakan bahan anestesi jenis lain dapat dilihat pada Tabel 12.

Tabel 12 menunjukkan alasan dokter gigi tidak pernah memakai bahan anestesi lain, 38,70\% atau 12 orang menjawab bahan anestesi yang digunakan sudah efektif, 5 
orang atau 16,12\% menjawab ketersediaan bahan yang digunakan lebih banyak dan 2 orang saja atau $6,45 \%$ memberikan jawaban harga bahan anestesi lokal yang dipakai lebih murah.

Tabel 12. Distribusi frekuensi berdasarkan alasan dokter gigi tidak pernah memakai bahan anestesi lainnya.

\begin{tabular}{lllc}
\hline $\begin{array}{l}\text { Alasan dokter gigi tidak } \\
\text { pernah menggunakan bahan } \\
\text { anestesi lain }\end{array}$ & n & \% \\
\hline $\begin{array}{l}\text { Bahan yang digunakan sudah } \\
\text { baik (efektif) }\end{array}$ & 12 & 38,70 \\
$\begin{array}{l}\text { Harga bahan yang sedang } \\
\text { digunakan lebih murah }\end{array}$ & 2 & 6,45 \\
$\begin{array}{l}\text { Ketersediaan bahan yang } \\
\text { digunakan lebih banyak }\end{array}$ & 5 & 16,12 \\
$\begin{array}{l}\text { Golongan bahan anestesi lokal } \\
\text { yang digunakan lebih baik }\end{array}$ & 4 & 12,90 \\
\hline Total & 31 & 100 \\
\hline
\end{tabular}

Bahan anestesi yang dokter gigi gunakan pada keadaan hipertensi, asma, penyakit jantung dan diabetes

Bahan anestesi yang dokter gigi gunakan pada keadaan hipertensi, asma, penyakit jantung dan diabetes dapat dilihat pada Tabel 13.

Tabel 13. Distribusi frekuensi berdasarkan penggunaan bahan anestesi pada pasien dengan keadaan hipertensi, asma, penyakit jantung dan diabetes.

\begin{tabular}{lcccc}
\hline \multirow{2}{*}{$\begin{array}{c}\text { Jenis } \\
\text { bahan } \\
\text { anestesi }\end{array}$} & \multicolumn{4}{c}{$\begin{array}{c}\text { Bahan anestesi yang digunakan pada } \\
\text { keadaan berikut (n / \%) }\end{array}$} \\
\cline { 2 - 5 } & $\begin{array}{c}\text { Hiper- } \\
\text { tensi }\end{array}$ & Asma & $\begin{array}{c}\text { Penyakit } \\
\text { jantung }\end{array}$ & Diabetes \\
\hline Lidokain & $18 / 58,06$ & $21 / 67,74$ & $24 / 77,41$ & $26 / 83,87$ \\
Artikain & $4 / 12,90$ & $6 / 19,35$ & $1 / 3,22$ & $3 / 9,67$ \\
Prokain & $5 / 16,12$ & $2 / 6,45$ & $2 / 6,45$ & - \\
Mepiva- & $4 / 12,90$ & $2 / 6,45$ & $4 / 12,90$ & $2 / 6,45$ \\
kain & & & & \\
\hline Total & $31 / 100$ & $31 / 100$ & $31 / 100$ & $31 / 100$ \\
\hline
\end{tabular}

Berdasarkan Tabel 13 menunjukan bahwa 18 orang dokter gigi atau 58,06\% menggunakan lidokain untuk pasien hipertensi, masing-masing 4 orang dokter gigi atau 12,90\% menggunakan artikain dan mepivakain, dan 5 orang dokter gigi atau $16,12 \%$ menggunakan prokain. Penggunaan bahan anestesi lokal pada pasien asma menunjukan bahwa 21 orang dokter gigi atau $67,74 \%$ menggunakan lidokain, 6 orang dokter gigi atau 19,35\% menggunakan artikain dan masing masing 2 orang dokter gigi atau 16,12\% menggunakan mepivakain dan prokain. Pada pasien dengan penyakit jantung menunjukan 24 orang dokter gigi atau $77,41 \%$ menggunakan lidokain, 1 orang atau 3,22\% menggunakan artikain, 2 orang atau $6,45 \%$ menggunakan prokain dan 4 orang atau 12,90\% menggunakan mepivakain. Sedangkan pada pasien diabetes menunjukan 23 orang dokter gigi atau 74,19\% menggunakan lidokain, 2 atau 6,45\% orang menggunakan artikain, dan juga 2 orang atau $6,45 \%$ menggunakan mepivakain.

\section{BAHASAN}

Hasil yang didapat dalam penelitian ini, menunjukkan bahwa Lidokain $\mathrm{HCl}$ 2\% merupakan bahan anestesi yang paling banyak digunakan oleh dokter gigi dalam pencabutan gigi tetap di kota manado dengan persentasi 74,19\% atau sebanyak 23 orang dokter gigi dari 31 orang responden. Dibandingkan dengan hasil penelitian yang dilakukan oleh Haas dan Gaffen di Ontario pada tahun 2007 yaitu penggunaan Lidokain dengan Epinephrine 1:100.000 merupakan bahan yang paling umum digunakan dengan persentase $37,31 \%{ }^{1}$

Penggunaan bahan anestesi lidokain didasarkan pada bekerja lebih cepat dan lebih stabil dari pada sebagian besar bahan anestesi lainnya. ${ }^{8}$ Alasan yang sama yang diberikan oleh dokter-dokter gigi di Ontario yaitu keefektifan dan kelarutan bahan menjadi alasan utama pemilihan bahan anestesi tersebut. Penggunaan bahan anestesi yang menjadi alasan lain yaitu ketersediaan bahan juga memiliki peranan penting.

Di dalam penelitian ini juga memperlihatkan gambaran alasan dokter-dokter gigi di kota Manado tentang pemilihan bahan anestesi. Dari hasil penelitian tersebut di dapat 90,32\% menjawab keefektifan bahan anestesi lokal merupakan alasan 
utama dalam pemilihan bahan tersebut. Penelitian ini dibandingkan dengan penelitian Corbett dkk antara tahun 2002 dan 2003 pada dokter gigi di United Kingdom (UK) yang paling sering dipilih karena efektivitas bahan anestesi lokal.?

Survei yang dibandingkan Corbett dkk dengan 911 dokter gigi di Jerman terdapat sedikit perbedaan. Penelitian di Jerman didapatkan 91\% pemilihan bahan anestesi didasarkan pada faktor resiko yang akan diterima oleh pasien. Pemilihan bahan anestesi juga didasarkan pada golongan bahan anestesi tersebut. Dari penelitian yang dilakukan sebanyak 22,58\% setuju dengan alasan tersebut.

Kriteria pemilihan bahan anestesi lokal didasarkan pada golongan bahan anestesi tersebut merupakan faktor penting, karena perbedaan kimia yang direfleksikan dalam perbedaan tempat metabolisme dan juga berkaitan dengan besarnya kemungkinan terjadi alergi. $^{9}$

Berdasarkan harga bahan anestesi juga merupakan suatu pertimbangan yang diberikan oleh dokter gigi. Penelitian ini menunjukkan sebanyak 19,35\% dokter gigi di Manado setuju dengan kriteria tersebut.

Dokter gigi tentunya memiliki penjelasan yang berbeda-beda tentang pemilihan bahan anestesi, dalam penelitian ini sebanyak 74,19\% dokter gigi memberikan alasan bahwa syarat ideal suatu bahan anestesi lokal yaitu mula kerjanya cepat dan bekerja lama serta tidak menyebabkan alergi. Menurut Samodro R tahun 2011 durasi kerja umumnya berkolerasi dengan kelarutan lemak. Anestesi dengan kelarutan lemak tinggi memiliki durasi yang lebih panjang, diperkirakan karena lebih lama dibersihkan dari dalam darah. ${ }^{9}$

Beberapa praktek dokter gigi dalam pemberian anestesi lokal masih menggunakan bahan-bahan kombinasi untuk anestesi lokal tersebut. Praktek dokter gigi di Manado, berdasarkan hasil penelitian ada 54,83\% menggunakan bahan kombinasi. Penggunaan bahan kombinasi anestesi lokal umumnya didasarkan untuk meminimalkan rasa sakit sebelum diberikan suntikan pada pasien. ${ }^{10}$
Beberapa alasan dokter gigi di kota Manado yang menggunakan kombinasi bahan anestesi lokal dikarenakan pasien takut terhadap rasa sakit sehingga perlu diberikan anestesi topikal terlebih dahulu dengan persentase 35,48\%. Selain itu, menghilangkan ketidaknyamanan terhadap injeksi anestesi menjadi pertimbangan dokter gigi di Manado.

Mengendalikan kecepatan injeksi dan teknik relaksasi yang tepat direkomendasikan juga oleh para ahli dalam mengurangi rasa sakit ketika dilakukan injeksi. Kemudian pertimbangan lainnya yaitu penggunaan jarum yang kecil pada saat injeksi dapat mengurangi rasa sakit serta trauma terhadap jaringan dan pembuluh darah. ${ }^{10}$

Dari penelitian yang dilakukan pada praktek dokter gigi di Manado didapat jumlah dokter gigi yang menggunakan jenisjenis bahan kombinasi anestesi lokal, 7 orang atau 22,58\% menggunakan benzokain dan lidokain, kemudian dari jenis benzokain dan prokain ada 2 orang atau 6,41\%. 1 orang atau $3,22 \%$ menggunakan benzokain dan artikain, dan 1 orang lagi menggunakan EMLA dan lidokain. Dalam penelitian ini juga ditemukan dokter gigi yang menggunakan bahan kombinasi anestesi dengan menggunakan jenis golongan bahan anestesi yang sama yaitu golongan amida diantaranya lidokain dengan artikain dan etidokain dengan lidokain.

Hasil penelitian ini menunjukkan ada banyak pilihan jenis bahan kombinasi yang dipilih oleh dokter-dokter gigi yang berpraktek di Manado. Perbedaan pemilihan jenis bahan kombinasi ini tentunya memperlihatkan karakteristik dari dokter-dokter gigi yang ada di Manado memiliki keanekaragaman tersendiri dalam pemilihan jenis bahan kombinasi untuk anestesi. Menurut Meechan JG tahun 2008 pada studi yang dilakukan lebih dari 500 dokter gigi di Inggris melaporkan bahwa 95\% menggunakan anestesi kombinasi. Lidokain dan benzokain adalah bahan kombinasi anestesi yang paling umum digunakan. ${ }^{11}$

Selain dari dokter gigi yang menggunakan bahan kombinasi anestesi, ternyata ada juga dokter gigi yang tidak menggunakan- 
112 Jurnal e-GiGi (eG), Volume 1, Nomor 2, September 2013, hlm. 105-114

nya. Dalam penelitian ini didapat, 12 orang atau 38,70\% memilih alasan bahwa tidak perlu digunakan bahan kombinasi karena dengan satu jenis bahan sudah cukup. Penelitian ini juga didapatkan 1 orang dokter gigi memberikan alasan bahwa anestesi topikal tidak terlalu berpengaruh ketika akan dilakukan injeksi.

Dalam penelitian ini, ada 31 dokter gigi yang memberikan jawaban dari pertanyaan tentang pemakaian jenis bahan anestesi lain, 16 orang atau 51,61\% menjawab ya dan 15 orang atau 48,38\% memberikan jawaban tidak. Dari 16 orang atau 51,61\% yang menjawab ya, kemudian ditanyakan jenis bahan anestesi lain yang digunakan tersebut. Didapat 10 orang atau 32,25\% menggunakan lidokain HCL 2\%, 1 orang atau 3,22\% menggunakan artikain HCL 4\%, dan masing-masing 2 orang atau 6,45\% menggunakan mepivakain HCL 2\% dan jenis anestesi lain yaitu benzokain dan chlor etil.

Lidokain HCL 2\% dengan epinephrine 1:100.000 memberikan anestesi pulpa selama sekitar 60 menit dan anestesi jaringan lunak selama 3 sampai 5 jam sedangkan lidokain $2 \%$ dengan perbandingan 1:50.000 epinephrine dapat mengurangi kontrol nyeri tambahan. Artikain di metabolit oleh asam articainic, yang aktif sebagai anestesi lokal dan tidak memberikan efek samping yang tidak diinginkan. Karena metabolisme artikain yang cepat dan dianggap sebagai obat yang aman untuk mengelola selama perawatan gigi jika membutuhkan anestesi yang lebih sesuai diperlukan. Mepivakain tersedia dalam dua formulasi yang berbeda yaitu $3 \%$ mepivakain tanpa vosokonstriktor dan 2\% mepivakain 1 : 20.000 levonodefrin. Karena mepivakain menghasilkan vasodilatasi yang kurang dari lidokain, dapat menjadi alternatif untuk anestesi lokal bila vasokonstriktor menjadi kontraindikasi. ${ }^{12}$

Berdasarkan keunggulan dari masingmasing bahan anestesi diatas, dapat dilihat bahwa dokter-dokter gigi di kota Manado memiliki pilihan tersendiri untuk setiap pasien yang akan melakukan pencabutan gigi tetap.

Hasil penelitian didapatkan 14 orang atau 45,16\% memberikan jawaban tidak pernah memakai bahan anestesi lainnya. Alasan dari para dokter tentu berbeda-beda, sebanyak 38,70\% atau 12 orang menjawab bahan anestesi yang digunakan sudah efektif. Penelitian untuk efektifitas bahan anestesi lokal dengan membandingkan dosis yang setara antara lidokain dan artikain ditemukan tidak ada perbedaan yang signifikan dalam keberhasilan anestesi gigi posterior rahang atas dengan pulpitis ireversibel. $^{13}$

Ketersedian bahan yang digunakan juga menjadi alasan dokter memilih suatu jenis bahan anestesi lain, didapat ada sebanyak 5 orang atau $16,12 \%$. Sedangkan harga bahan anestesi lokal yang murah turut menjadi pertimbangan dokter gigi, ada 2 orang atau $6,45 \%$ yang memberikan alasan tersebut. Ditinjau dari golongan bahan anestesi lokal yang digunakan lebih baik, menjadi alasan dari 4 orang dokter gigi dalam penelitian ini memilih alasan tersebut.

Pada keadaan atau riwayat sistemik terlihat bahwa 18 orang dokter gigi atau $58,06 \%$ menggunakan lidokain untuk pasien hipertensi, masing-masing 4 orang dokter gigi atau $12,90 \%$ menggunakan artikain dan mepivakain, dan 5 orang dokter gigi atau $16,12 \%$ menggunakan prokain. Pemilihan menggunakan lidokain didasarkan pada tidak terdapatnya epinefrin. Penelitian menunjukkan bahwa epinefrin pada anestesi lokal gigi memiliki efek pada tekanan darah. $^{14}$

Pasien dengan riwayat asma menunjukkan bahwa 21 orang dokter gigi atau $67.74 \%$ menggunakan lidokain, 6 orang dokter gigi atau $19.35 \%$ menggunakan artikain, 2 mepivakain dan 2 orang dokter gigi atau $16,12 \%$ menggunakan prokain. Dalam penelitian yang dilakukan di UK oleh Corbett dkk antara tahun 2002 dan 2003 untuk pengelolaan pasien asma, tiga perempat praktisi dilaporkan menggunakan lidokain/epinefrin. Lebih banyak praktisi yang berpengalaman secara signifikan menunjukkan penggunaan prilokain/felipresin dibandingkan dengan lulusan praktisi baru. ${ }^{7}$

Pasien penyakit jantung menunjukan 24 orang dokter gigi atau $77.41 \%$ meng- 
gunakan lidokain, 1 orang atau 3.22\% menggunakan artikain, 2 orang atau $6.45 \%$ menggunakan prokain dan 4 orang atau $12.90 \%$ menggunakan mepivakain. Penelitian yang dilakukan di UK bahwa pemilihan prilokain /felipresin meningkat drastis ketika merawat pasien dengan penyakit kardiovaskular. Mayoritas praktisi memilih cara ini atau dengan cara pemberian epinefrin bagi pasien yang memiliki miokardiak infark dalam enam bulan sebelumnya. Epinefrin tidak di indikasikan sebagai tindakan pencegahan karena mungkin khronotropik jantung, inotropik dan sifat aritmogenik, efek yang mungkin berlebihan pada beberapa pasien, seperti transplantasi jantung. Namun, itu juga telah menyarankan felipresin bahwa pada konsentrasi tinggi dapat menghasilkan vasokonstriktor koroner/iskemia dan dalam penggunaan dengan kondisi jantung tersebut dapat menjadi kontraindikasi. ${ }^{7}$

Pasien dengan keadaan yang memiliki diabetes, 23 orang dokter gigi atau $74.19 \%$ menggunakan lidokain, 2 atau $6.45 \%$ orang menggunakan artikain, dan juga 2 orang atau $6.45 \%$ menggunakan mepivakain. Penelitian ini tidak jauh berbeda dengan penelitian yang dilakukan oleh Puneet Kalra pada tahun 2011, dimana pada pasien diabetes diberi injeksi lidokain dan setelah 10 menit didapatkan peningkatan glukosa darah tidak terlalu signifikan. ${ }^{15}$

\section{SIMPULAN}

Terdapat 2 orang atau $6,45 \%$ dokter gigi di Manado memilih penggunaan bahan anestesi lokal berdasarkan golongan ester yaitu prokain dan benzokain. Penggunaan jenis bahan anestesi lokal golongan ester pada pasien riwayat hipertensi sebanyak $16,12 \%$ dan pasien dengan riwayat asma dan penyakit jantung sebanyak 6,45\%.

Lidokain $\mathrm{HCl} 2 \%$ merupakan bahan anestesi lokal golongan amida yang paling banyak digunakan oleh dokter gigi di kota Manado dengan persentase 74,19\% diikuti artikain $\mathrm{HCl} 4 \%$ 16,12\% dan mepivakain $\mathrm{HCl}$ 2\% 3,22\%. Penggunaan bahan anestesi lidokain didasarkan pada bekerja lebih cepat dan lebih stabil dari pada sebagian besar bahan anestesi lainnya. Gambaran alasan dokter-dokter gigi di kota Manado tentang pemilihan bahan anestesi mayoritas menjawab keefektifan bahan anestesi lokal merupakan alasan utama. Kemudian golongan bahan anestesi, harga bahan serta ketersediaan bahan di pasaran juga menjadi alasan pemilihan bahan tersebut.

Penggunaan bahan anestesi lokal dengan kombinasi golongan ester dan amida oleh dokter-dokter gigi di Manado sebanyak $54,83 \%$ dengan alasan yang paling banyak dikarenakan pasien takut terhadap rasa sakit sehingga perlu diberikan anestesi topikal terlebih dahulu dengan persentase $35,48 \%$.

\section{DAFTAR PUSTAKA}

1. Gaffen AS, Haas DA. Survey of local anesthetic use by Ontario dentists. J Can Dent Assoc. 2009;75(9):649.

2. Kirova D, Lalabonova Hr, Dobreva D. A survey of local anesthetic agents used by bulgarian dental practitioners. J of IMAB. 2005;2:7-8.

3. Balaji SM. Textbook of oral and maxillofacial surgery. New Delhi: Elsevier, 2007; p.167-70.

4. Malamed SF. Handbook of local anesthetic (Sixth Edition). St. Louis: Mosby-Year Book Inc, 1997; p.14-7.

5. McLure HA, Rubin AP. Review of local anaesthetic agents. Minerva anestesiol. 2005;71:59-74.

6. Snoeck M. Articaine: a review of its use for local and regional anesthesia. Local Reg Anesth. 2012;5:23-33.

7. Corbett IP, Ramacciato JC, Groppo FC, Meechan JG. A survey of local anesthetic use among general dental practitioners in the UK attending postgraduate courses on pain control. BDJ 2005; 199(12):784-7.

8. Neal M.J. At a glance farmakologi medis. (Edisi Kelima). Jakarta: Erlangga medical series, 2007; p.16.

9. Samodro R, Sutiyono D, Satoto HH. Mekanisme kerja obat anestesi lokal. Jurnal Anestesiologi Indonesia. 2011;3(1):50-3.

10. Scarlett MI. Local anesthesia in today's dental practice. Continuing education course. 2010 July 22. p.4.

11. Meechan J.G. Intraoral topical anesthesia. Periodontology. 2000;46(2008):56-57. 
114 Jurnal e-GiGi (eG), Volume 1, Nomor 2, September 2013, hlm. 105-114

12. Logotheis D. Local anesthetic agents: A review of the current options for dental hygienists. CDHA journal. 2011;27(2):7-8.

13. Fried C.C, Bashutski J, Rashidi N. a comparison of equivalent doses of lidocaine and articaine in maxillary posterior tooth extractions: case series. Journal of oral \& maxillofacial research. 2012;28;3(2);5.

14. Bader J.D, Bonito A.J, Shugars D.A. Low risk of adverse effects from epinephrine in hypertensive patients, but relevant high-quality literature is sparse. Summary review oral medicine. 2002;93:86.

15. Kalra P, Rana A.S, Peravali R.K. comparative evaluation of local anesthesia with adrenaline and without adrenaline on blood glucose concentration in patients undergoing tooth extactions. 2011 mei 26; Springer. p. 235. 